\title{
KORPORASI DALAM HUKUM ORGANISASI BISNIS ISLAM
}

\author{
Windi Afdal \\ * Konsultan Hukum SAFE Law Firm \\ Korespondensi:windiafdal@gmail.com \\ Naskah dikirim: 23 Juni 2016 \\ Naskah diterima untuk diterbitkan: 16 September 2016
}

\begin{abstract}
This article critically examine the reason of the delay in introducing Islamic law into the form of corporate business to help Muslim society in their economic activity. In addition, this study also aims to provide an explanation regarding the legal validity of the concept of corporate legal personality in Islamic law. This study aplied the method of juridical-normative research by using socio-legal analysis. The article conclude that: (1) Delayed development of corporate business organizations in the Muslim world caused by; the view that organizing community by using corporate form can damage the vision of united ummah because it can lead to factionalization in the community; The lack of capital resources because it endowment institution on wakaf; stagnant institutional development of business organizations in Islamic law; and last the capital group of Merchant class could not consolidated because hard for them to keep persistence on capital accumulation for accross generations and for conglomeration activity. (2) Fuqoha actually understand the concept of personality legal and it aplicable to non-humans corpus, but they are reluctant to develop this concept because it can't work the legal system that they have created. Therefore, the formation of a nonhuman corpus actually possible in Islam by rule rely on assiyasah syariyah as the ulil domain domain (political authority).
\end{abstract}

Keywords: Corporation, Personality Legal, Islamic Law.

\begin{abstract}
Abstrak
Artikel ini kritis memeriksa alasan penundaan dalam memperkenalkan hukum Islam ke dalam bentuk bisnis perusahaan untuk membantu masyarakat muslim dalam aktivitas ekonomi mereka. Selain itu, penelitian ini juga bertujuan untuk memberikan penjelasan mengenai validitas hukum dari konsep kepribadian hukum perusahaan dalam hukum Islam. Penelitian ini menerapkan metode penelitian yuridis-normatif dengan menggunakan analisis sosio-legal. Artikel ini menyimpulkan bahwa: (1) pengembangan Tertunda organisasi bisnis perusahaan di dunia Muslim yang disebabkan oleh; pandangan bahwa pengorganisasian masyarakat dengan menggunakan bentuk perusahaan dapat merusak visi bersatu ummat karena dapat menyebabkan faksionalisasi di masyarakat; Kurangnya sumber daya modal karena wakaf institusi di wakaf; pengembangan kelembagaan stagnan dari organisasi bisnis dalam hukum Islam; dan terakhir kelompok kelas pedagang tidak bisa dikonsolidasikan karena sulit bagi mereka untuk menjaga ketekunan pada akumulasi modal bagi generasi accross dan untuk kegiatan konglomerasi. (2) Fuqoha benar-benar mengerti konsep kepribadian hukum dan dapat diterpkan manusia non corpus, tetapi mereka enggan untuk mengembangkan konsep ini karena tidak dapat bekerja sistem hukum yang telah mereka ciptakan. Oleh karena itu, pembentukan badan non-manusia sebenarnya mungkin dalam Islam oleh aturan mengandalkan assiyasah syariyah sebagai domain ulil domain (otoritas politik).
\end{abstract}

Kata kunci: Korporasi, Kepribadian Hukum, Hukum Islam.

Tersedia versi daring: http://jhp.ui.ac.id DOI: http://dx.doi.org/10.21143/jhp.vol47.no3.95 


\section{Pendahuluan}

Secara numerik pertumbuhan sektor ekonomi syariah khususnya perbankan syariah memang memang cukup fantastis bahkan sampai dengan tiga digit. Sebagai sebuah trend fenomena global, indonesiapun tidak terkecuali. Dalam penilaian Global Islamic Financial Report (GIFR) tahun 2011 Indonesia menduduki peringkat keempat negara dengan potensi dan kondusif bagi pengembangan industri keuangan syariah setelah Iran, Malaysia dan Arab Saudi. ${ }^{1}$ Berdasarkan beberapa aspek perhitungan indeks, seperti jumlah bank syariah, jumlah lembaga keuangan non-bank syariah maupun ukuran asetnya Indonesia bahkan diperkirakan akan meduduki peringkat pertama dalam satu dasawarsa kedepan. Optimisme tersebut diyakini sejalan dengan laju ekspansi kelembagaan dan akselerasi pertumbuhan aset perbankan syariah yang cukup tinggi terlebih dengan tingginya permintaan atas sukuk dipasar keuangan.

Sayangnya proyeksi tersebut belum berjalan sesuai harapan bila melihat timbulnya paradoks antara aspek kelembagaan dan aset. Berdasarkan data terakhir secara kelembagaan ekonomi syariah di Indonesia berada diurutan ketiga di dunia namun dari asetnya hanya berada di urutan ke sembilan. ${ }^{2}$ Pertumbuhan market share sektor perbankan syariah terhadap kapitalisasi perbankan nasional justru cenderung melambat setidaknya dalam lima tahun terakhir secara berturut-turut mulai dari $2.61 \%, 3.24 \%, 3.98 \%, 4.58 \%$, dan terakhir ditahun 2014 hanya berkisar diangaka 5.3\%. Hal demikian tentunya cukup ironis jika melihat potensi pasar tradisional yang tersedia dari komposisi jumlah penduduk muslim di Indonesia yang mencapai $87.18 \%$ dari total populasi 237.641 .326 jiwa. $^{3}$

Berdasarkan data tersebut dapat disimpulkan bahwa peran institusi kelembagaan sektor ekonomi syariah di Indonesia masih terbilang kecil dalam kapitalisasi modal di Indonesia. Hal demikian cukup kontras bila dibandingkan dengan apa yang terjadi pada kasus di Malaysia. Di Malaysia kebijakan difokuskan untuk membangun institusi keuangan syariah yang kuat sehingga sekalipun secara kuantitas kelembagaan tidak semeriah di Indonesia namun institusi yang dibangun memiliki efektifitas 4 kali lipat lebih baik daripada Indonesia. Hal tersebut tercermin berdasarkan statistik GIFR tahun 2013 dimana ketika dana aset ekonomi syariah di Indonesia mencapai \$35 Milyar dolar AS di saat yang sama malaysia sudah menembus angka $\$ 115$ Milyar dolar AS. ${ }^{4}$ Meski

1 Global Islamic Finance Report, Islamic Finance Country Index (IFCI), (London: Manor Creative Ltd, 2011).

2 Data yang dikeluarkan Muktamar III Ikatan Ahli Ekonomi Islam Indonesia (IAEA) yang diselenggarakan pada tanggal 30 April 2015 di kantor Kementerian Keuangan Jakarta.

3 Badan Pusat Statistik (BPS), Jumlah dan Distribusi Penduduk Tahun 2010, <http://sp2010.bps.go.id/>, diakses 15 Juni 2016.

${ }^{4}$ Ibid. 
memiliki gradasi yang berbeda antar negara, penulis melihat tetap saja secara umum, baik di Indonesia maupun negara muslim lainnya pertumbuhan ekonomi syariah memang cukup menjanjikan dari segi kuantitas kelembagaan namun sayangnya tidak pada kualitas kelembagaan. Contoh sukes hanya terjadi pada sebagian kasus namun tidak pada isu bentuk organisasi bisnisnya, instrumen keuangan maupun produk derivatifnya. Akumulasi persoalan inilah yang barangkali menjadi penyebab terjadinya perlambatan pertumbuhan ekonomi syariah dalam beberapa tahun terakhir.

Permasalahan kelembagaan merupakan tantangan yang dihadapi pemikir Islam dalam merumuskan model organisasi yang tepat dalam mengaplikasikan prinsip ekonomi syariah. Perpaduan antara model organisasi yang tidak sesuai (compatible) dengan prinsip ekonomi syariah menyebabkan praktik yang berjalan tidak sesuai dengan harapan. Implikasi dari praktek tersebut menimbulkan melemahnya kepercayaan publik terhadap institusi ekonomi Islam yang dalam akumulasinya akan memperlemah kemampuan Insitusi itu sendiri dalam menghimpun modal. Sekalipun persoalan ini mulai mendapatkan tempat dalam studi islam beberapa abad terakhir namun sayangnya pemecahan masalah yang ditawarkan tidak pernah benar-benar tuntas. ${ }^{5}$ Untuk mengurai "kegamangan" insitusional tersebut, sebagai langkah permulaan penulis melihat tidak ada jalan yang lebih baik selain berpaling pada landasan kesejarahan. Semakin kita objektif dalam menilai aspek kesejarahannya niscaya semakin mudah bagi ahli hukum Islam dalam merumuskan formula hukumnya.

\section{Gerakan Korporasi Di Dunia Muslim}

Tahun 1851 merupakan saat ketika perusahaan persekutuan modal muslim (muslim owned joint stock company) pertama kali didirikan oleh Imperium Turki Usmani dan diresmikan dengan nama Shariket Hayriye (Perusahaan Pengangkutan Laut). Berkantor pusat di Istambul, kepemilikaanya terbagi dalam 2000 lembar saham yang dapat diperdagangkan. Pada saat itu Imperium baru saja memulai gerakan reformasi kelembagaan (tandzimat) yang didalamnya termasuk pembenahan infrastruktur hukum. Pengadilan Niaga dibentuk untuk menegakkan aturan Kitab Undang-Undang Hukum Dagang Prancis yang baru saja diintrodusir kedalam hukum Turki, adapun bursa efek saat itu belumlah ada. Meskipun demikian Shariket Hayriye dapat memulai kegiatan bisnisnya dibawah patronase Sultan Abdulmecit selaku pemegang saham mayoritas. Adapun sisa saham lainnya dibeli oleh

5 Hal ini dapat kita cermati dari rekomendasi yang dihasilkan Konferensi Internasional Tentang Ekonomi Islam ke-6 yang ternyata luput memperhatikan pentingnya diskursus desain organisasi bisnis dalam Islam untuk kepentingan akselerasi penerapan ekonomi syariah, lihat Abdul Ghofur Anshori, Perbankan Syariah di Indonesia, (Yogyakarta: Gadjah Mada Press, 2007), hal 28-30. 
sejumlah pejabat tinggi negara yang umumnya keturunan Turki sementara sebagian kecil lainnya dimiliki oleh pemodal swasta keturunan Armenia. ${ }^{6}$

Karena kurangnya padanan bahasa Turki, Shariket Hayriye dikarakteristikkan Sultan Abdulmecit sebagai padanan kata "kumpaniye", "compagnie" dalam bahasa Prancis atau "Company" dalam bahasa Inggris. Namun apa sebenarnya motif diperkenalkannya bentuk organisasi asing yang tak ubahnya seperti "alien" tersebut kedalam Hukum Islam, yang secara tradisional didasarkan pada kontrak komersial. Dalam pengamatannya, Sultan Abdulmecit melihat bahwa perekonomian Imperium Turki Usmani saat itu digerakkan oleh pelbagai perusahaan yang utamanya dimiliki oleh sekelompok minoritas asing oleh karena itu menurutnya kinilah saatnya orang Turki maupun ummat Muslim pada umumnya untuk ambil bagian dalam tren bisnis pengelolaan sumber daya ekonomi melalui kumpaniyes. Kebutuhan untuk mentransformasi organisasi binis sebenarnya telah dikemukakan elit pemerintahan pada pertengahan abad ke-19 Masehi yang melihat model partnership yang didasarkan pada fiqih klasik tidak lagi sesuai untuk perkembangan sektor perbankan, lalu lintas keuangan, dan sektor manufaktur. Faktanya mereka menyadari pula bahwa hukum kontrak Islam nyaris tidak pernah berubah sejak abad ke-10 Masehi sehingga kondisinya tidak lagi sesuai dengan realitas perekonomian global. ${ }^{7}$

Dari sisi pengembangan model organisasi bisnis saat itu, Shariket Hayriye memiliki keunggulan dari sifat sahamnya yang dapat diperdagangkan. Dalam model Islam klasik, partnership akan berakhir apabila ada sekutu yang mengundurkan diri, atau matinya salah satu atau lebih anggota sekutu. Ketika model organisasi bisnis tersebut dilakukan menurut fiqih klasik maka pastilah sulit untuk mendorong tumbuhnya investasi dan persekutuan untuk jangka panjang. ${ }^{8}$ Kelemahan dari model organisasi bisinis klasik tersebut diatasi Shariket Hayriye dengan kemampuan untuk menerbitkan dan memperdagangkan saham sehingga perusahaan tetap bisa bertahan sekalipun terjadi peralihan pemegang saham yang didesain mudah untuk diperalihkan tanpa harus memperbaharui perjanjian pendiriannya. Walau bagaimanapun satu hal yang patut digarisbawahi ternyata saat itu Shariket Hayriye tidak dinyatakan sebagai bentuk perseroan terbatas (korporasi). Pembentukannya sebagai perusahaan persekutuan modal bukan berbadan hukum membuatnya tidak memiliki personalitas hukum. Menjadi

6 David Lendes, Bankers And Pashas: International Finance And Economic Imperalialism in Egypt, (Cambridge: Harvard University Press, 1958), hlm. 149-154. lihat pula Timur Kuran, The Long Divergence, (New Jersey: Princenton University Press, 2013).

${ }^{7}$ David Lendes, op.cit, hlm. 83-84, 149-154 .

${ }^{8}$ Timur Kuran, The Islamic Commercial Crisis: Institutional Roots of Economic Underdevelopment in the Middle East, "Journal of Economic History”, Vol. 63, (2003), hlm. 414-446. 
pertanyaan menarik kemudian, kenapa Sultan tidak menyatakan saja Shirket-i Hayriye sebagai korporasi pertama yang dibentuk, disetujui dan diakui pemerintah.

Karakteristik utama yang merupakan keunggulan dari model organisasi korporasi adalah kesederhanaan aspek litigasinya. Selain itu sifat pertanggungajawaban terbatasnya melindungi aset dan kekayaan korporasi dari tuntutan pemenuhan kewajiban dari setiap pemegang saham. Hal yang patut dicermati disini adalah perlunya dibedakan perlindungan bagi pemegang saham (owner shilelding) dan perlindungan bagi korporasi (entity shielding) sebagai entitas hukum mandiri. Model organisasi bisnis yang bukan berbadan hukum (termasuk sejumlah model partnership dalam fiqih klasik) memberikan owner shilelding kepada partner sehingga harta dan kekayaan pribadi dari partner tersebut dapat dilindungi dari tuntutan kewajiban kreditor partner lainnya atau dalam kata lain hal inilah yang menimbulkan konsep pertanggunjawaban terbatas bagi pemegang saham. Namun tidak satupun dari model partnership tersebut yang dapat memberikan entity shielding yang didalamnya memberikan perlindungan bagi korporasi itu sendiri. Tanpa adanya entity shielding kelangsungan usaha dari organisasi bisnis tersebut akan lebih singkat karena secara teoritis setiap kreditor bahkan dapat menuntut dilakukannya likuidasi untuk kepentingan pelunasan kewajiban yang ditimbulkan oleh salah seorang pemegang saham. ${ }^{9}$ Jika pendirian organisasi tersebut melahirkan personalitas hukum serta adanya pemisahan kekayaan (seperti halnya korporasi) maka dengan sendirinya organisasi bisnis tersebut mendapatkan dua jenis perlindungan tersebut.

Shariket Hayriye tentu saja memiliki keuntungan dari patronase yang diberikan Sultan Abdulmecit. Menyadari kuatnya komitmen personal dari Sultan, kreditor pemegang saham tentu perlu berfikir dua kali untuk menuntut dilakiduidasinya aset Shariket Hayriyem. Bagi perusahaan dengan model organisasi semacam itu tetapi tidak mendapatkan patronase Sultan tentu akan lebih rentan dan sulit untuk menyerap modal masyarakat. Dan memang benar, lima puluh tahun sejak didirikannya Shariket Hayriye, kebanyakan perusahaan-perusahaan yang dibentuk di Turki Usmani merupakan perusahaan asing yang berkantor pusat di London atau Prancis dan umumnya mereka memilih mekanisme penyelesaian sengketa melalui lembaga ajudikasi di luar negeri. Adapun perusahaan-perusahaan Turki yang umumnya dikuasai non-Muslim lebih memilih choice of forum lembaga hukum asing. ${ }^{10}$ Citacita Sultan untuk merangsang partisipasi dan pertumbuhan kumpaniye masyarakat muslim Turki baru benar-benar terwujud setelah disetujuinya Undang-Undang Korporasi Turki tahun 1908. Pengalaman historis

\footnotetext{
9 Henry Hansmann, et. al., Law and the Rise of the Firm, "Harvard law Review”, Vol. 119, (2006), hlm. 1337-1343.

10 Pola yang sama terjadi untuk kasus mesir tahun 1920an, lihat Robert L. Tignor, The Introduction of Modern Banking into Egypt 1855-1920, "Asian \&Africa Studies”, Vol. 15, (1981), hlm. 103-122.
} 
tersebut setidaknya menunjukkan bahwa alternatif model organisasi bisnis yang tidak memiliki personalitas legal tidak akan mampu untuk menggantikan peran dan fungsi korporasi.

Tulisan ini bertujuan untuk menyibak misteri kenapa korporasi sebagai model organisasi bisnis baru masuk dan diterima di dunia Muslim setelah abad ke-20 M. Tantangan untuk menjawab pertanyaan tersebut akan coba diuraikan melalui tiga sub bab pokok. Pertama, penjelasan kenapa selama masa formulasi fiqih, Hukum Islam seakan menutup diri dari kemungkinan konstruksi hukum korporasi. Kedua, menentukan penyebab kenapa setelah abad-abad permulaan Islam konsep entitas korporasi maupun lembaga sejenisnya tidak mengalami perkembangan berarti. Pertanyaan tersebut akan menjawab bagaimana masyarakat Timur Tengah dan dunia Islam pada umumnya mengelola organisasi bisnisnya yang disaat bersamaan pada masyarakat Eropa umumnya dijalankan dengan purwarupa model korporasi. Ketiga, kenapa sekalipun masyarakat barat telah menunjukkan keunggulankeunggulan model organisasi bisnis korporasi, pemerintahan Muslim saat itu tidak langsung mentransplantasinya kedalam hukum Islam.

\section{Resistensi Islam Dalam Menerima Konsep Korporasi.}

Periode formulasi fiqih yang berlangsung selama abad 7 Maesehi10 Masehi merupakan masa-masa yang menentukan dalam pembentukan institusi hukum di dunia Muslim. Meluasnya daulah Islam yang membentang dari Andalusia di Barat sampai Dinasti Moghul di Timur berarti pula meningkatkan sumber kekayaan negara dari pengutan zakat, jizyah, kharaj (pajak tanah), uhsr (bea cukai), khumus (harta temuan), nawaib (pajak konglomerasi), serta utamanya ghanimah. ${ }^{11}$ Dalam konteks ini fiqih Islam diarahkan untuk menciptakan distribusi ekonomi dengan mencegah terjadinya pemusatan kekayaan kepada sekelompok kecil masyarakat, pada saat bersamaan usaha tersebut dibarengi dengan upaya korektif terhadap tradisi masa lalu yang sarat dengan pengaruh tradisi hukum arab tribal dan Romawi. Pekerjaan besar yang dihadapi fuqoha tersebut tentu tidaklah mudah karena disamping hukum Islam didesain untuk memenuhi tuntutan relijiusitas yakni keselamatan akhirat harus pula dapat menjawab kebutuhan praktis dalam keseharian ummat Muslim. Dalam konteks ini perangkat hukum Islam merupakan manifestasi konsep keseimbangan dunia dan akhirat.

Apabila kita mencermati perangkat sosial yang tersedia pada masyarakat Muslim abad pertengahan segala prakondisi yang mendukung terbentuknya organisasi korporasi sudah tersedia bagi para fuqoha untuk menyusun organisasi korporasi. Berdasarkan institusi hukum yang telah dikembangkan, sulit dipercaya bahwa fuqoha tidak

${ }^{11}$ Adiwarman Karim, ed., Sejarah Pemikiran Ekonomi Islam, (Jakarta: IIIT, 2002), hlm. 35 . 
mengetahui manfaat atau keunggulan adanya sebuah personalitas legal yang mendukung organisasi korporasi. Alih-alih mengadopsi konsep korporasi, fuqoha lebih memilih untuk mengembangkan institusi sosial tersendiri yang sejalan dengan paradigma fiqih yang tengah dibangun. Usaha-usaha tersebut sebagian berhasil dengan cemerlang untuk satu waktu tertentu namun dalam perkembangan selanjutnya gagal merespon perubahan di Masyarakat. Keberhasilan tersebut bisa kita cermati dengan merujuk pada hegemoni konglomerasi Karimi dil laut merah, begitu pula catatan khusus Madison bahwa tak seorangpun pedagang China dan Italia yang akan melihat bahwa timur tengah sebagai daerah yang tertinggal dan terbelakang. Hal demikian menjadi sebuah hal yang kontras ketika pengusaha Eropa dan China melihat Timur Tengah di permulaan abad 20 Masehi yang nyaris terbelakang disegala aspek. ${ }^{12}$

Dari sisi teori sosial, terdapat beberapa penjelasan kenapa organisasi korporasi tidak berkembang dalam sistem Hukum Islam. Pertama, berkenaan dengan filsafat sosial yang membentuk masyarakat muslim itu sendiri dimana organisasi korporasi dilihat sebagai instrumen yang dapat memfasilitasi perpecahan ummat. Kedua, mandeknya perkembangan institusi sosial pasca berakhirnya formulasi fiqih di abad ke-10 Masehi. Ketiga, sistem sosial yang dibentuk ditujukan untuk mencegah terjadinya akumulasi modal ketangan sekelompok kecil Individu.

\section{Korporasi: Instrumen Yang Dapat Memecah belah Umat}

Penekanan Islam pada masalah landasan sosial merupakan cerminan dari kewajiban yang termuat dalam al-Quran. Penekanan Islam pada visi persatuan ummat sebagai kerangka bangunan masyarakat tercermin dalam tugas yang dimuat dalam Al-Qur'an. Setidaknya ada delapan ayat yang berisi seruan perintah untuk mengajak pada kebaikan dan mencegah kepada kemungkaran. Empat di antaranya ditujukan kepada individu sedangkan sisanya merupakan kewajiban kolektif ummat Islam (ummath). Pada kenyataannya teks al-Quran tidak menyatakan bentuk praktis bagi model organisasi ummat Islam tersebut. Begitu pula larangan membentuk organisasi untuk mencapai tujuan kolektif ummat, bahkan tak satupun istilah yang disebutkan secara tegas. Dengan demikian tak satupun aktor kolektif dalam masalah ekonomi yang disebutkan dalam al-Quran begitu pula peristilahan yang merujuk pada badan hukum. Dengan kata lain dapat disimpulkan bahwa sumber utama yang memandu kehidupan ummat muslim tidak menyatakan secara jelas dukungannya terhadap korporasi sebagai model organisasi bisnis atau setidaknya memperkenankan ummat muslim untuk menstransplantasikannya dari sumber hukum lain di luar Islam.

${ }^{12}$ Lihat Angus Maddison, Monitoring the World Economy 18201992(Paris:OECD, 1995),hlm. 55-56. Maddison bahkan memperkirakan pendapatan perkapita masyarakat timur tengah saat itu diatas masyarakat Eropa. 
Ada penjelasan kenapa pada fase permulaaannya, Islam ada kecenderungan untuk menolak konsep yang memungkinkan terciptanya faksionalisasi. Yang paling utama ialah kekhawatiran terjadinya perpecahan karena bangkitnya fanatisme kesukuan, dan dalam kondisi tersebut negara memiliki kemampuan untuk menghambat pertumbuhan institusi sosial yang dapat memicu bangkitnya bentuk solidaritas baru. ${ }^{13}$ Sebagaimana yang terjadi dibarat lembaga organisasi korporasi dianggap sebuah ancaman terhadap persatuan ummat, karena melalui insitusi legal tersebut faksionaliasi dan segregasi kelompok masyarakat terbuka. Selain itu kuatnya eksistensi negara merupakan faktor pendukung bagi terciptanya kontrol yang ketat atas setiap aktifitas pengimpunan kekuatan sosial ditengah masyarakat.Untuk mengisi kekosongan institusional itu penguasa Muslim lebih cenderung mendukung organisasi wakaf dan Commenda/Partnership.

\section{Stagnansi Perkembangan Institusi Sosial}

Sejarawan terkemuka abad 20 Joseph Kohler berpendapat bahwa hal utama yang menjadi penyebab runtuhnya hegemoni Islam disebabkan oleh tidak terbukanya ruang dalam fiqih bagi studi pengembangan Institusi sosial. ${ }^{14}$ Hal ini dapat kita cermati dengan memperbandingkan perkembangan antara institusi sosial di Barat dan Islam misalnya wakaf dan korporasi. Sekalipun memiliki persamaan dari sisi kontinuitas organisasi, ada perbedaan mendasar diantara keduanya. Pertama, sebuah perkumpulan dapat berubah menjadi korporasi bila sesuai dengan kehendak para pendirinya secara kolektif, sedangkan wakaf biasanya didirikan oleh satu orang. Kedua, dalam pengendaliannya sebuah korporasi ditentukan dengan mengganti anggota didalamnya, sedangkan wakaf secara teoritis tetap dikendalikan oleh pendirinya sesuai arahan yang ditetapkan dalam ikrar wakafnya (waqfiyya). Dengan demikian, tujuan pendirian wakaf bersifat irrevocable, bahkan sekalipun pendiri yang sah tersebut bermaksud untuk menarik pernyataannya dengan ikrar baru yang berlaku surut. Perbedan ketiga terdapat dari sisi pengorganisasiannya. Berbeda dengan fleksibilitas yang terdapat dalam organisasi korporasi, sifat dan ketentuan wakaf sudah ditentukan; arah dan tujuan yang telah ditetapkan pendirinya dalam ikrar wakaf akan ditegakkan oleh hakim, sementara bila ikrarnya tidak tertulis atau tidak jelas hukumnya akan disesuaikan dengan kebiasaan setempat.

Seperti halnya gereja yang tidak secara langsung menemukan konsep korporasi itu begitu saja, ${ }^{15}$ demikian pula konsep wakaf tidaklah

\footnotetext{
${ }^{13}$ Bandingkan dengan lemahanya eksistensi negara di Wilayah Eropa Barat saat berada dibawah Imperium Tahta Suci Romawi Barat

14 Udovitch, op.cit., hlm.17.

15 Pasca berlangsungnya papal revolution atau yang dikenal pula dengan Gregorian Reform, institusi gereja mulai mengidentifikasi dirinya sebagai "korporasi" yang mandiri dan diperlakukan oleh penguasa sebagai institusi personalitas semu, lihat
} 
muncul tiba-tiba dari ruang hampa. Konsep wakaf berasal dari lembaga trust sebenarnya sudah ada sejak tradisi hukum romawi, dan dimasa praIslam, masyarakat di Timur Tengah sudah menggunakannya dalam pelbagai bentuk. Menjadi pertanyaan, kenapa ummat Muslim lebih memilih model trust namun menolak model korporasi? Meski belum ada bukti yang menunjukkan hal demikian, dipilihnya lembaga wakaf karena dianggap lebih sesuai dengan visi komunal Islam. Sepanjang pemimpin Islam melihat faksionalisasi sebagai sebuah ancaman, tidaklah heran bila mereka lebih menyukai bentuk organisasi yang didirikan dan dikelola oleh Individu daripada model organisasi yang memungkinkan pengorganisasian kelompok secara legal.

Alasan kenapa penguasa lebih menerima wakaf dan menolak korporasi tidak akan kami uraikan lebih lanjut, kecuali berkenaan dengan penjelasan kenapa individu itu sendiri ingin mendirikan wakaf. Dua alasan utama diantaranya adalah soal kedermawanan dan gengsi. Terkadang kedua alasan tersebut tidak ada hubungannya dengan layanan jasa yang diberikan. Selain itu tidak jarang bila wakaf dipengaruhi oleh motif untuk mendapatkan keuntungan ekonomis bagi wakif itu sendiri dan keluarganya. Seaorang wakif memungkinkan untuk menunjuk dirinya sendiri sebagai nadzir/mutawali (pengelola harta wakaf), menentukan gajinya sendiri, mempekerjakan kerabatnya sendiri, dan bahkan menunjuk penggantinya, sesuai dengan hukum waris Islam. Dengan mendonasikan harta tersebut sebagai aset wakaf akan membuatnya menjadi lebih aman. Melalui instrumen wakaf, keinginan penguasa untuk mengambil alih harta pribadi akan terhalang. Oleh karena itu, wakaf dapat berfungsi sebagai sarana penampungan harta. Kualitas perlindungan yang diberikan lembaga wakaf tersebut ditentukan pada sakralitasnya sebagian didasarkan pada legitimasi hukum Islam sementara sebagian yang lain pada penghargaan publik atas niat yang mulia dari wakif. Dengan keyakinan bahwa harta tersebut menjadi suci setelah diwakafkan akan menyurutkan langkah penguasa untuk menyitanya, karena hal itu sama saja dengan perbuatan fasik.

Seperti halnya wakif yang menginginkan pengamanan terhadap harta wakafnya, pemerintahpun demikian meski tidak tersedia peluang untuk mengambil alih aset wakaf namun pemerintah wajib memastikan komitmen wakif untuk memberikan pelayanan publik sesuai dengan peruntukan harta wakaf. Mengawasi nadzir untuk mematuhi akta ikrar wakaf salah satu caranya. Dengan kata lain, lembaga Wakaf memang dirancang tidak fleksibel untuk mencegah permasalahan yang timbul bagi nadzir dikemudian hari dalam pelaksanaan ikrar wakaf.

Prinsip "Kekekalan yang Tetap" yang muncul dari wakaf sebanarnya merupakan bagian dari kesepakatan diam-diam antara penguasa dan pemilik harta. Bahwa tawar-menawar tersebut

Thomas Donaldson, Corporation and Morality (New Jersey:Prentice Hall, 1982), hlm. 4. 
menyebabkan terciptanya inefisiensi hendaklah dipahami sebagai jalan darurat yang dilembagakan untuk merespon kebutuhan mendesak pada masanya. Akan tetapi sayang sekali flesibilitasnya sangatlah terbatas. Disejumlah tempat dan waktu tertentu standar baku pembentukan wakaf dimuat dalam sebuah daftar yang memungkinkan adanya sejumlah perubahan dalam operasionalisasinya. Meski demikian, hanya satu ketentuan yang dapat dirubah, dan sekali dilakukan perubahan maka konsep kekekalan harta wakaf akan berlangsung selamanya. Oleh karena itu, cepat atau lambat penilaian dan pertimbangan dari nadzir, pekerja dan pihak-pihak lainnya yang sebelumnya menerima manfaat akan kehilangan perhatiannya, dan pada prinsipnya baik tujuan dan mode organisasinya akan ketinggalan zaman. Bagaimana bila tiba pada satu titik ketika tujuan tersebut tidak lagi tercapai, misal terjadi perubahan rute perdagangan yang mengakibatkan penginapan/rumah singgah yang dibiayai wakaf itu menjadi tidak berguna lagi. Dalam keadaan demikian dapatkah tujuan wakaf disesuaikan kembali? Sejauh hukum yang dipahami pada umumnya, nadzir/pengelola harta wakaf tidak memiliki kewenangan untuk itu. Jika terjadi kondisi demikian, demi hukum harta pendukung wakaf tersebut akan disumbangkan bagi kepentingan orang miskin. Selain itu, perwujudan dari konsep kekekalan tersebut dengan adanya pembatasan tujuan bagi dua atau lebih lembaga wakaf yang dibentuk untuk mencari keuntungan termasuk menurut ukuran ekonomis.

Apapun motif yang mendasari ciri karakteristik dari lembaga wakaf, untuk jangka waktu yang lama jelas tidak efisien. Hal ini terlihat sangat kontras bila kita membandingkan pembentukan perguruan tinggi di Timur Tengah melalui pembiayaan wakaf bernama madrasah dan hal yang serupa didirikan di barat yang kini kita kenal dengan Universitas. Universitas-universitas pertama di Eropa, seperti Paris (1180) dan Oxford (1249), pada awalnya didirikan melalui lembaga trust yang serupa dengan wakaf. ${ }^{16}$ Akan tetapi dengan cepat mereka menjelma menjadi organisasi yang mandiri dari pengaturannya dan memperbaharui pengorganisasiannya melalui korporasi-yayasan. Sebaliknya, madrasah terus terkekang oleh batasan yang ditetapkan wakifnya. Seiring berjalannya waktu kurikulum pendidikan di Madrasah nyaris tidak berubah bila dibandingkan perkembangan yang berlangsung di Universitas, hal inilah yang mendorong tenggalamnya Timur Tengah pada era keterbelakangan Intelektual. Meskipun banyak faktor lainnya yang mempengaruhi kemunduran inteektualitas di Timur Tengah setelah berlangsungnya abad-abad kejayaan pada masa pemerintahan Islam, salah satu persoalannya adalah menyangkut terbatasnya mode pengorganisasian wakaf.

Madrasah dan perguruan tinggi keduanya sama-sama merupakan organisasi nirlaba. Perbedaan diantara keduanya muncul dimilenium

${ }^{16}$ Lihat kajian Monica M. Gaodiosi, The Influence of The Islamic Law Waqf on The Development of The Trust in England:The Case on Merton College, "P.A. Law Review", 1988, hlm. 136. 
kedua dan dapat ditelusuri dari jalan berbeda yang mereka tempuh setelah kelahiran Islam. Wakaf telah menjadi bentuk organisasi utama dalam Islam yang terbatas fungsinya sebagai penyedia layanan sosial sementara disaat yang bersamaan korporasi pun digunakan masyarakat barat untuk tujuan yang sama. Kesenjangan pngorganisasian tersebut semakin melebar memasuki abad ke-16 Masehi, ketika Barat mulai mengembangkan organisasi korporasi untuk kegiatan bisnis, sementara untuk layanan sosial fungsi korporasi ditansformasikan menjadi yayasan. Adapun lembaga wakaf hingga saat ini tidak berubah seakan diawetkan seperti mumi.

Stagnansi organisasi bisnis ini dapat pula dicermati dalam tulisan Ron Harris mengenai Dinamika Institusional antara Korporasi di Barat dan Commenda di Timur Tengah. ${ }^{17}$ Dalam analisisnya persebaran organisasi bisnis sangat dipengaruhi oleh aspek geoografis dan dinamis dari suatu kebudayaan hukum. Commenda/Partnership seperti akad musyakarah dan mudharabah menyebar dari kebudayaan hukum arab keseluruh dunia karena selain sangat praktis tipe kontrak tersebut sangatlah universal sehingga dapat diterapkan disegala kondisi. Sebaliknya korporasi untuk waktu yang lama hanya bisa bervolusi di wilayah Eropa Barat karena karakternya melekat dalam suatu kebudayaan hukum tertentu.

\section{Sulitnya Akumulasi Modal Secara Berkesinambungan}

Islam mengakui kepemilikan pribadi dan memperkenankan setiap orang untuk dapat mencari nafkah sepanjang mengikuti tata cara permainan yang adil. Tata cara permainan yang adil tersebut memperkenankan setiap individu mengumpulkan harta sepanjang tidak bertentangan dengan prinsip ekonomi Islam termasuk dengan mendistribusikan kekayaannya itu. Dilarangnya sistem riba serta pembayaran zakat merupakan intrumen Islam untuk mewujudkan visi keadilan sosialnya dengan mencegah terjadinya penumpukan kekayaan pada sekelompok kecil masyarakat.

Dalam hukum Islam visi tersebut diimplementasikan kedalam pelbagai lapangan hukum. Sebagai sebuah institusi bisnis yang memiliki fungsi utama sebagai sarana penghimpunan modal tentu hadirnya korporasi sejalan dengan kebutuhan kelompok pengusaha. Sekalipun sektor perdagangan tidak dapat merubah tatanan sosial secara langsung namun dalam pelbagai praktik, konglomerasi seperti Karimi memiliki modal sosial yang cukup untuk menanamkan pengaruhnya melalui penguasa formal negara. ${ }^{18}$ Namun kelompok saudagar Islam ini gagal

17 Lihat Ron Harris,The Institusional Dynamicf of Early Modern Eurasian Trade:The Commenda and the Corporation, (Tel Aviv: Buchmann Faculty of Law, 2008).

18 Subhi Y. Labib, Capitalism in Medieval Islam, "The Journal of Economic History”, Vol. 29, 1969, hlm. 81. 
melakukan konsolidasi guna memperkuat pengaruh politiknya dalam pengambilan kebijakan publik, terlebih untuk kepentingan pertahanan kekayaan.

Ketika konsolidasi kelompok borjuis Eropa berhasil menanamkan pengaruhnya kepada penguasa politik untuk mendukung pembentukan korporasi bisnis, konglomerasi Islam seperti Karimi tidak berhasil melakukan hal yang serupa. Hal ini menunjukkan lemahnya konsolidasi kelompok pengusaha di dunia Islam dalam mekanisme pengambilan kebijakan publik. Alih-alih mendukung korporasi, kelompok pengusaha gagal meyakinkan fuqoha selaku pemegang otoritas hukum Islam serta Sulthan selaku pemegang otoritas politik untuk memberikan legitimasi atas eksistensi korporasi bisnis yang dapat menghimpun modal secara efektif.

Dalam kaca pemerintah, ketika sekelompok orang diberi akses dan pengakuan legal untuk berhimpun dalam institusi formal diluar negara, hal itu sama artinya dengan terbukanya kemungkinan penciptaan faksionalisasi ditengah masyarakat. Selain itu dari sisi kebijakan fiskal, pengakuan atas personalitas legal korporasi dianggap dapat menngurangi pajak negara. Dalam logika pemerintah akan lebih baik bila mekanisme aneka pungutan pajak tetap dipertahankan kepada individu. Hal demikian tidak jauh berbeda dari perspektif pragmatis kelompok sarjana Islam, hadirnya korporasi dapat menekan permintaan legal opinion yang menjadi layanan jasa mereka.

Tidak terkonsolidasinya kelompok pengusaha Islam dapat disebabkan pelbagai faktor, seperti sulitnya akumulasi modal secara berkesinambungan antar generasi maupun antar konglomerasi. Akumulasi dan kesinambungan kapital ini sangat penting dalam menentukan kekuatan elit konglomerasi. Sebagaimana dijelaskan oleh Winters dalam teori oligarkinya, sumber kekuatan politik dari oligarki yang membedakannya dengan elit lainnya adalah pada penguasaannya pada sumber daya kapiltal. ${ }^{19}$ Untuk dapat mempengaruhi kebijakan formal baik terhadap otoritas agama maupun ototritas politik saudagar seperti Karimi haruslah dapat menciptakan tatanan norma yang mendukung basis pertahanan kekayaannya. Pengakuan terhadap korporasi akan memperkuat basis pertahanan kekayaan itu bagi generasi karimi selanjutnya ataupun saranan penghimpunan konsolidasi modal antara saudagar lainnya. Apabila hal ini terjadi maka generasi Karimi akan dapat mempertahankan hegemoninya kepada penguasa.

Namun hal demikian tidak terwujud, kekuatan organisasi Karimi tidak berlanjut pasca meninggalnya al-Yasir ataupun al-Din (Karimi terkaya). Faktor utama penyebab masalah ini adalah terkait dengan praktik kewarisan Islam. Tujuan untuk mencegah terjadinya penumpukan kekayaan tersebut dalam hukum waris dilembagakan melalui lembaga

${ }^{19}$ Lihat pembedaan elit berdasarkan sumber kekuasaannya dalam Jeffrey A. Winters, Oligarcy, (New York:Cambridge, 2011),hlm. 12. 
ab-intestato dalam islam (faraidh) yang menetapkan bagian-bagian yang tegas dan detil atas harta waris sekaligus membatasi mekanisme kewarisan secara testamentier (wasiat). Akibatnya begitu Seorang Karimi meninggal akumulasi modal tidak dapat dipertahankan mengingat harta peninggalan (tirkah) dari Karimi tersebut harus dibagi sesuai ketentuan faraidh. Ketika kekayaan tersebut dibagi, generasi selanjutnya tidak memiliki posisi yang cukup kuat untuk berhadapan dengan otoritas politik dan agama. Begitupula ketentuan kallalah dalam hukum waris Islam yang memungkinkan negara mengambil alih kekayaan seorang pewaris kedalam kas baitul maal.

\section{Validitas Personalitas Legal Korporasi Dalam Hukum Islam}

Penaklukan Mekkah (Fathu Makkah) merupakan salah satu peristiwa penting dalam perkembangan kebudayaan Islam. Saat itu tepatnya pada tahun $630 \mathrm{M}$ atau bertepatan dengan tanggal 10 Ramadan tahun 8 Hijriyah, Nabi Muhammad beserta 10.000 pasukan bergerak dari Madinah menuju Mekah. ${ }^{20}$ Tidak lama berselang, melalui pergerakan cepat dan tidak terduga Rasullullah SAW yang mulai bertolak selepas ashar telah menguasai kota Mekkah secara keseluruhan tanpa pertumpahan darah berarti. Hal pertama yang diperintahkan Rasulullah tatkala kota Mekah dibebaskan adalah penghancuran segala bentuk thagut/berhala atau sesembahan kaum kafir Quraish yang sebelumnya telah dilembagakan kebudayaan arab pra-Islam totem dengan pelbagai nama seperti Latta, Uzza dan sebagainya.

Peristiwa penghancuran totem/berhala tersebut sebenarnya bukan perintah yang baru dalam tradisi agama samawi dimana risalah kenabian selalu ditujukan untuk menghancurkan setiap sendi-sendi kebudayaan yang bertentangan dengan prinsip ajaran monoteisme. Meskipun demikian penulis melihat peristiwa penghacuran berhala itu memiliki arti penting yang menentukan sikap Ulama abad pertengahan terhadap penerimaan konsep personalitas legal dalam tradisi hukum Islam sekalipun hal itu disadari atau tidak. ${ }^{21}$

Dalam bagian ini penulis akan menjabarkan bagaimana konsep personalitas legal itu dipahami dalam pendekatan fiqih abad pertengahan. Tesis yang coba didukung penulis sebagaimana telah dikuatkan oleh kajian-kajian sarjana kontemporer bahwa konsep personalitas legal bukannya tidak dipahami ulama Muslim abad pertengahan akan tetapi konsep personalitas legal tersebut tidak dapat diterima dalam konteks fiqih saat itu karena akan bertentangan dengan konsep personalitas legal yang sedang disusun oleh ulama saat itu. Meskipun demikina pada

\footnotetext{
${ }^{20}$ Abdullah Haidar, Sejarah Hidup dan Perjuangan Rasulullah SAW, disarikan dari Kitab Ar-Rahiqul Makhtum karya Syekh Shafiyyur-Rahman Mubarakfur(Riyadh: Kantor Da'wah dan Bimbingan Bagi Pendatang al-Sulay KSA, 2005) hlm.174.

21 Totem/berhala pada hakikatnya merupakan bentuk pengakuan paling purba dari kebudayaan manusia terhadap eksistensi subjek hukum selain manusia.
} 
bagian akhir, penelusuran lebih jauh terhadap organisasi korporasi mengarah pada kesimpulan bahwa Fiqih Islam dapat menerima konsep personalitas legal, namun penerimaan terhadap konsep tersebut bukanlah unsur yang esensial terhadap keberatan fiqih terhadap organisasi korporasi.

Untuk dapat menjawab validitas personalitas legal korporasi dalam perspektif hukum Islam maka usaha pertama yang perlu dilakukan adalah mengenali konsep personalitas legal itu sendiri baik dalam pengertiannya dalam hukum barat baru kemudian mengkomparasikannya dengan terminologi fiqih. Setelah pengertian itu disepakati dalam satu kesepahaman maka barulah dapat ditentukan jawaban persoalan tersebut.

\section{Konsep Person dan Personalitas Legal}

Sebelumnya penulis telah menyingggung betapa tidak mudahnya menjumbuhkan suatu terminologi hukum yang telah mapan dari satu sistem hukum terhadap sistem hukum lainnya. Dalam tradisi hukum barat subyek hukum dipahami sebagai segala sesuatu yang dapat menyandang hak dan kewajiban karena itu tidak jarang istilah subyek hukum dan person hukum dalam pemahaman hukum dapat dijumbuhkan. Namun menurut penulis penggunaan istilah subyek hukum kurang akurat untuk konteks penulisan ini karena subyek hukum itu sangatlah luas bergantung pada obyek materialnya apakah itu dilapangan hukum privat ataupun hukum publik ataupun hukum nasional ataupun hukum Internasioanal yang satu atau krena lain hal memiliki batasan subyeknya masingmasing. Oleh karena itu untuk kepentingan akademis disini penulis cenderung untuk menggunakan terminologi teknis person ${ }^{22}$ untuk mempertegas pengertiannya dalam lapangan hukum privat.

Begawan hukum belanda Van Apeldoorn mendefinisikan persoon sebagai segala sesuatu yang mempunyai persoonlijkheid. Adapun yang dimaksud dengan personalitas hukum atau persoonlijkheid itu adalah kecakapan untuk menjadi subyek hukum. ${ }^{23}$ Dengan demikian menurut Van Apeldoorn personalitas hukum adalah unsur yang esensial dalam pengertian persoon. Sehingga sesuatu itu tidak dapat disebut persoon tanpa adanya persoonlijkheid. Menurut penulis pengertian yang diberikan tersebut tidak sepenuhnya akurat karena adakalanya suatu persoon itu tidak memiliki persoonlijkheid. Sebagai contoh misalnya adalah budak, anak yang belum dewasa sebagaimana dimaksud pasal 330 Kitab Undang-Undang Hukum Perdata secara faktual adalah persoon namun karena hukum belum memiliki persoonlijkheid.

Dalam hal ini pengertian persoon dan personlijkheid yang dikemukakan oleh Salmon menjadi penting untuk disimak. Salmon

${ }^{22}$ Dalam ejaan Belanda "person" (Inggris) ditulis "persoon"

${ }^{23}$ L.J. van Apeldoorn, Pengantar Ilmu Hukum, terjemahan Oetarid Sadino, (Jakarta: Pradnya Paramita, 2001), hlm. 191. 
mendefinisikan persoon sebagai setiap orang yang kepadanya dapat dibebankan hak-hak serta kewajiban atau dalam pengertian lain istilah person berarti setiap orang yang oleh hukum dinilai cakap dan dapat dibebani hak-hak dan kewajiban sepanjang terpenuhinya syarat-syarat legal yang ditentukan hukum untuk mendapatkan kapasitas melakukan perbuatan hukum. ${ }^{24}$ Pengertian yang diberikan Salmon tersebut menurut penulis lebih memadai karena dengan definisi tersebut berarti tidak setiap person itu memiliki personalitas legal, adapun sesuatu itu dapat dikatakan person dalam pengertian hukum apabila terpenuhinya dua unsur yakni:a). Juris Korpus, yakni wadah fisik tempat bernaungnya personalitas legal, korpus disini dapat dimanifestasikan dalam bentuk manusia, sekumpulan orang, dan sebagainya; b). Atribusi Hukum Atas Juris Korpus yang membuat suatu korpus memiliki personalitas legal. ${ }^{25}$

Dengan demikian person dapat dipahami sebagai salah satu bentuk saja dari korpus, adapun personalitas merupakan atribusi hukum yang diberikan terhadap korpus atau person sehingga membuatnya memiliki kapasaitas legal sebagaimana pengertian person yang dimaksud oleh Van Apeldoorn. Manfaat dari pengertian Salmond tersebut dapat diaplikasikan untuk menjelaskan status budak dan anak dibawah umur tadi. Baik budak maupun anak dibawah umur merupakan person karena merupakan korpus dalam wujud manusia akan tetapi karena hukum mereka tidak memiliki atau belum mendapatkan atribusi hukum yang membuatnya memiliki kapasitas hukum untuk menjadi personalitas legal. Selain itu berdasarkan manifestasi korpusnya, persoon tersebut dapat pula dibedakan menjadi naturalijk persoon (subyek hukum dengan wujud fisik manusia) dan recht persoon (subyek hukum dengan wadah semu).

Dalam fiqih klasik terma personalitas dapat dikaitkan dengan terma mukallaf, akan tetapi padanan ini memiliki keterbatasan dalam perkembangan pemikiran hukum kontemporer konsep mukallaf itu selalu dan hanya merujuk pada korpus dalam wadah fisik manusia. Dengan kata lain mukallaf hanya dapat dipahami terbatas pada pengertian naturalijk persoon. Selain itu pengertian mukallaf dalam terminologi fiqih lebih luas dan mencakup setiap orang yang dapat dibebani syariat baik dalam konteks hukum ibadah maupun muamalah. Dengan demikian terminologi ini kurang tepat untuk dijumbuhkan dengan terminologi personalitas dalam teori hukum modern yang disamping hanya bekerja dalam lingkup sekuler(dunia an sich) juga mengenal persoon dalam pengertian selain manusia seperti perseroan terbatas dan yayasan.

Untuk mengatasi persoalan tersebut istilah person dalam terminologi fiqih kontemporer diintrodusir menjadi istilah shaksiyyah yang mencakup shakhsiyyah haqiqiyah maupun shaksiyyah i'tibariyah. Person dikatakan shakhsiyyah haqiqiyah(naturalijk persoon) bila

24 Sir John William Salmond, On Jurisprudence, (Delhi:Universal Law Publishing, 2010), hlm. 351.

25 Ibid. 
merujuk pada subyek hukum manusia, adapun yang dimaksud dengan shaksiyyah i'tibariyah merupakan person selain manusia (recht persoon). ${ }^{26}$ Dalam pandangan penulis upaya ini tidak serta merta menyelesaikan masalah karena penggunaan istilah ini tidak disandarkan pada landasan fiqih tertentu yang apabila digali lebih dalam sebenarnya memiliki spesifikasi terminologi yang lebih detil dan kompleks bila dibandingkan dengan terminologi yang pada dalam teori hukum barat.

Beberapa istilah erat relevansinya dengan masalah personalitas legal adalah terminologi ahliyah dan dhimmah. Ahliyah secara bahasa berarti kemampuan atau kecakapan, dengan demikian secara umum pengertian menurut bahasa ini sangatlah luas. Untuk kepentingan teknislegal para fuqaha memberikan pengertian hukum Ahliyah sebagai kemampuan atau kecakapan untuk mendapatkan hak-hak serta mempergunakan dan menerima kewajiban-kewajiban hukumnya itu. Berdasarkan pengertian ini fiqih membedakan dua bentuk persoonlijkheid yakni dalam pengertian pertama sebagai kemampuan untuk mendapatkan hak-hak atau dalam istilah fiqih disebut dengan ahliyah al wujuh dan kedua sebagai kemampuan untuk bertindak atau ahliyah al-ada'. Ahliyah al wujuh menjadi dasar seseorang untuk dapat menerima hak-hak dan kewajiban hukum, sedangkan ahliyah al-ada' menjadi dasar bagi seseorang untuk dapat melakukan perbuatan hukum. ${ }^{27}$

Pembedaan tersebut sangat bermanfaat dalam memberikan penjelasan terhadap personalitas yang melekat pada seorang budak atau anak yang belum dewasa atau seseorang yang dibawah pengampuan. Seorang budak tidak memiliki personalitas secara mutlak baik dalam pengertian ahliyah al wujub maupun ahliyah al-ada' sehingga sekalipun dia merupakan person namun karena tidak adanya kapasitas untuk menerima hak dan kewajiban ataupun kapasitas untuk bertindak maka dia tidak dikulifikasikan sebagai person yang memiliki personalitas. Sementara itu seorang anak yang dibawah umur memiliki personalitas secara terbatas yakni ahliyah al-wujub sehingga dia dapat menerima hakhak dan kewajiban hukum seperti bagian atas tirkah namun dia tidak memiliki ahliyah al-ada' sehingga diperlukan wali untuk bisa mewakili anak itu dalam melakukan perbuatan hukum.

Istilah fiqih selanjutnya yang relevan untuk disandingkan dengan personalitas adalah dhimmah. Sebagian fuqaha menjumbuhkan terminologi dhimmah dengan ahliyah al-wujub namun mayoritas ulama berpendapat terminologi dhimmah mengacu pada agregasi dari ahliyah al-wujub dan ahliyah al-ada'. Sehingga sesuatu itu baru dikatakan dhimmah apabila memuat kapasitas untuk menerima hak dan kewajiban hukum sekaligus kemampuan untuk bertindak/melakukan perbuatan

${ }^{26}$ Imran Ahsan Khan Nyazee, Fikih Korporasi: Membincang Hukum Organisasi Bisnis Dalam Islam, diterjemahkan oleh Nafis Irkhami, dkk., (Salatiga: STAIN Salatiga press, 2008), hlm.152.

${ }^{27}$ Muhammad Abu Zahrah, Ushul Fiqih, (Jakarta: Pustaka Firdaus, 2014),hlm. 351. 
hukum. Dengan kata lain Dhimmah merupakan rumah tempat melekatnya ahliyah sehingga tidak heran apabila ada yang berpendapat bahwa Dhimmah merupakan terminologi yang paling mendekati pengertian dan kandungan unsur personalitas dalam teori hukum Islam.

Apabila dilakukan tela'ah lebih lanjut terhadap istilah teknis dalam sejumlah karya fiqih ternyata pernyataan tersebut tidak pula sepenuhnya akurat karena Dhimmah memiliki dimensi yang lebih luas daripada personalitas. Al-Sharaksi memberikan definisi literal dhimmah sebagai "amanat" atau "kepercayaan". Hal itu ditarik al-Sharaksi dari al-Quran Surat Al-Ahzab ayat 72 yang terjemahan bebasnya: "Sesungguhnya kami telah menawarkan amanat kepada langit, bumi, dan gunung-gunung, tetapi semuanya enggan untuk memikul amanat itu dan mereka khawatir tidak akan (mampu) melaksanakannya, lalu dipikulah amanat itu oleh manusia....". 28 Disini al-Sharaksi mengikatkan dhimmah sebagai kapasitas legal dalam lapamngan hukum dunia dan akhirat, sesuatu yang tidak akan kita temukan dalam konsep personalitas dalam tradisi hukum barat.

\section{Penerimaan Konsep Personalitas Legal Dalam Hukum Islam}

Konsep Personalitas legal korporasi merupakan isu hukum utama jika bukan yang paling utama menarik minat sarjana muslim tatkala oraganisasi bisnis korporasi diintrodusir dalam menerapkan sistem ekonomi Islam. Terhadap masalah tersebut setidaknya muncul tiga pandangan menyangkut penerimaan konsep personalitas legal korporasi, diantaranya:

a. Pandangan yang menyimpulkan bahwa tidak ada landasan kuat dalam fiqih yang dapat mendukung eksistensi recht persoon dalam hukum Islam;

b. Pandangan yang menyimpulkan bahwa fiqih telah meletakkan landasan yang cukup dalam mendukung hadirnya recht persoon dalam hukum hukum Islam;

c. Pandangan yang menyimpulkan konsep recht persoon tidak memiliki landasan dalam fiqih namun eksistensinya diperlukan oleh masyarakat sehingga dituntut lahirnya ijtihad. ${ }^{29}$

Pandangan pertama didukung oleh orientalis seperti Joseph Schacht dan Abraham L.Udovitch, sementara Nyazee Khan memasukkan Isa Abduh sebagai salah satu Sarjana Muslim pendukung pendangan ini. ${ }^{30}$ Argumen utama dari kelompok ini didasarkan bahwa dalam studi fiqih tidak ditemukan adanya landasan yang kuat yang mendukung eksistensi recht persoon.

${ }^{28}$ Al-Sharaksi, Kitab al Ushul, jilid 2, hal 332, sebagaimana telah dikutip pula oleh Nyazee Khan, Fiqih Korporasi, op.cit, hlm.156.

${ }^{29}$ Khan, op.cit, hlm. 138 .

${ }^{30}$ Ibid. 
Joseph Schacht menambahkan bahwa lembaga bayt al-mal dan wakaf tidak dapat dijadikan sandaran yang mendukung penerimaan personalitas legal buatan bagi sistem hukum Islam klasik. Dalam hal ini Joseph Schact terkesan berada dalam konflik akademik karena pendapat tersebut seakan hanya untuk menguatkan thesis yang dibangunnya bahwa hukum Islam baru terbentuk setelah berlangsungnya formulasi fiqih pada akhir abad pertama hijriah (abad ketujuh Masehi) dan mencapai bentuk yang mapan pada abad ketiga hijriyah (lebih kurang abad kesembilan Masehi). ${ }^{31}$ Sebelum periode itu ummat Muslim masih mendasarkan hukum kebiasaannya pada tradisi arab pra-Islam yang kental dengan pengaruh hukum romawi. Adapun baik hukum romawi pada masa itu maupun hukum Islam pasca berakhirnya formulasi fiqih belum sampai pada perkembangan pemikiran hukum semaju itu untuk bisa menciptakan prototype personalitas legal. Satu-satunya konsep fiqih yang paling dekat pada konsep ini menurut Shcacht adalah aqi'lah. ${ }^{32}$

Sementara itu pengamatan yang lebih komprehensif dari Abraham L.Udovitch agaknya lebih bisa diterima obyektifitasnya. Melalui penelitiannya terhadap karya al-Sharaksi terkait partnership pada masa abad pertengahan di dunia Muslim, tidak diketemukan adanya indikasi kuat bagi eksistensi personlitas legal. Meski demikian Udovitch melihat adanya peluang untuk itu dengan mendasarkan pendapat-pendapat alSharaksi terhadap konsep partnership yang telah dipraktekkan pada masa lalu.

Pandangan kedua yang mendukung penerimaan personalitas legal korporasi mendasarkan argumentasinya pada eksistensi lembaga wakaf, bayt al-mal serta harta tirkah yang dianggap merepresentasikan adanya persoonlijkheid dimana institusi tersebut dalam praktiknya seolah diperlakukan seperti persoon semu yang dapat memiliki kekayaan ataupun menyandang kewajiban-kewajiban hukum. Pendapat ini dikemukakan oleh Abd al-Qadir Awdah yang menyatakan:

Syariah sejak awal kemunculannya telah mengakui recht persoon. Hal ini didasarkan pada pandangan fuqaha yang menganggap bayt al-mal dan wakaf sebagai sebuah institusi yang memiliki personalitas legal. Demikian pula halnya madrasah-madrasah, rumah sakit, dan lain sebagainya. Insitutusi tersebut memiliki kapasitas legal untuk memiliki harta kekayaan dan dapat pula memanfaatkan kekayaannya itu. ${ }^{33}$

Pendapat Awdah ini sebagaimana seringkali dikemukakan oleh Nyazee merupakan landasan utama bagi pendukungnya, adapun argumentasi ini kemudian berulang kali direproduksi oleh pendukung teori kontrak syarikah.

31 Joseph Schacht, An Introduction to Islamic Law (New York: Oxford University Press, 1982), hlm.10-49.

${ }^{32}$ Ibid., hlm.125.

${ }^{33}$ Abd. Al Qadir Awdah, Al Tasyri' al-jina'i al-Islami, Jilid I, (Beirut: Mu'assat al Risalah, 1992), hlm. 393., sebagaimana dikutip pula oleh Khan, op.cit, hlm.139. 
Pandangan ketiga merupakan pandangan paling moderat dalam polemik mengenai personalitas legal korporasi. Pendapat ini didasarkan pada hasil penelusuran ilmiah sebagaimana kesimpulan pandangan kelompok pertama yang tidak berhasil menemukan landasan yang kuat bagi eksistensi personalitas legal korporasi dalam tradisi hukum Islam. Meski demikian kelompok ini melihat lebih jernih sekalipun tidak memiliki landasan hukum tetap diperlukan adanya ijtihad yang dapat mendukung eksistensi personalitas legal itu mengingat hal tersebut merupakan fondasi lahirnya korporasi dengan cita rasa Islam.

Berdasarkan analisis diatas penulis berpendapat bahwa sekalipun tradisi fiqih klasik menunjukkan adanya pemikiran yang mengarah pada pembentukan korporasi namun sulit dibuktikan bahwa fiqih klasik mengakui konsep personalitas legal korporasi. Pernyataan ini didasarkan karena tidak terbuktinya pendapat kedua yang menganggap personalitas legal terhadap korpus non-manusia dapat diterima dengan mengqiyaskan pada insitusi wakaf dan baitul maal.

Insitusi wakaf tidak dapat menjadi sandaran karena tidak ditemukannya karakteristik personalitas legal pada institusi tersebut. Pada hakekatnya wakaf hanyalah suatu konstruksi hukum yang mendasari pemisahan suatu objek harta dari harta pribadi seorang wakif untuk digantungkan selama waktu tidak tertentu untuk tujuan tertentu. Didalam institusi wakaf tidak terdapat ahliyah al-wujuh dan ahliyah alada yang menjadi dasar bersemayamnya status dhimmah. Adapun status gallah (penerimaan harta wakaf) yang dianggap sebagai manifestasi dari karakteristik ahliyah wakaf adalah keliru karena gallah itu sendiri bukanlah perlekatan dari wakaf itu sendiri melainkan hak dari beneficiary wakaf yang direpresentasikan oleh nadzir.

Argumentasi yang dibangun untuk diqiyaskannya personalitas legal korporasi dengan baitul maal lebih lemah lagi. Pendapat ini dibangun dengan mendasarkan eksistensi baitul maal sebagai bentuk mal musytarak (kepemilikan kolektif) dari sebuah syarikat al-milk oleh karena itu dalam praktek dia diperlakukan seakan-akan personalitas semu yang memiliki ahliyah dalam bentuk menampung penerimaan dan membayar sejumlah kewajiban. Argumentasi ini kontradiktif karena esensi personalitas legal tidaklah timbul karena adanya kepemilikan kolektif melainkan ketika entitas tersebut mengidentifikasi dirinya sebagai entitas yang mendiri atau dengan kata lain, baitul maal hanya dapat diakui sebagai personalitas legal hanya dan hanya jika harta-harta dan kewajiban yang melekat padanya adalah milik dan tanggungjawabnya sendiri. ${ }^{34}$

Pada kenyataannya baitul maal hanyalah korpus yang tidak memiliki atribusi sebagai personalitas legal melainkan bentuk syarikat al milk dari ummat Islam dimana wakil dari ummat tersebut

\footnotetext{
${ }^{34}$ Konsep inilah yang menjiwai prinsip separate legal entity pada organisasi korporasi yang pada akhirnya membentuk entity shielding.
} 
dinstitusionalisasikan oleh lembaga imamah yang terbatas memiliki kewenangan pengurusan administratif (bestuurdaad) an sich. Tidak adanya pengakuan kepemilikan harta baitul maal oleh baitul maal sendiri dapat kita cermati pada pendapat hukum Imam Abu Hanifah, Syafi'i, Ahmad dan Syiah Zaydiyah yang menyimpulkan pengenaan hadd bagi pencuri harta baitul maal sebagai subhat. ${ }^{35}$

Penulis berpendapat bahwa sekalipun tradisi fiqih klasik menunjukkan adanya pemikiran yang mengarah pada pembentukan korporasi namun sulit dibuktikan bahwa fiqih mengakui konsep personalitas legal korporasi. Sekalipun demikian konsep personalitas legal dapat diterima sepanjang dilakukakannya sejumlah penyesuian dan klarifikasi ilmiah dari tinjauan fiqih terhadap organisasi korporasi.

Ditolaknya konsep personalitas legal oleh fuqoha abad pertengahan disebabkan adanya persepsi yang berbeda mengenai personalitas legal tersebut. Dalam Islam, fuqoha mengembangkan suatu sistem hukum yang menjangkau aspek kehidupan dunia dan akhirat secara bersamaan. Oleh karena itu konsep personalitas dipahami sebagai bentuk kemandirian perbuatan subjek hukum meliputi dimensi dunia maupun transendental di alam akhirat. Oleh karena itu fuqoha melihat konsep personalitas legal dalam pengertian terminologi dhimmah.

Terminologi dhimmah ini memang sangat serupa dengan konsep personalitas dalam hukum barat bahkan dalam uraian sebelumnya terminologi dhimmah ini lebih detil daripada konsep personalitas itu sendiri. Namun disamping itu ada perbedaan mendasar dari jangkauan hukumnya, dimana dhimmah ini tidak hanya menjangkau aspek duniawi namun juga dimensi akhirat. Oleh karena itu setiap bentuk personalitas dalam Islam haruslah dapat dibebani hak dan kewajiban dunia dan akhirat. Dalam pemikiran fuqoha, dhimmah hanya bisa diberikan kepada manusia saja atau dalam istilahan hanya terbatas pada mukallaf saja. Apabila suatu institusi memiliki status personalitas maka bagaimana bisa membebaninya dengan kewajiban ibadah.

Tidak diragukan lagi, fuqoha sebenarnya memahami berlakunya konsep dhimmah bagi corpus selain manusia, akan tetapi mereka enggan mengembangkan konsep ini karena tidak dapat bekerja dalam sistem hukum yang diciptakan oleh fuqoha.Terkait persoalan ini sebenarnya kewenangan pembentukan dhimmah non-manusia sebenarnya merupakan wilayah siyasah syariyah yang menjadi domain ulil amri (political authority). Pertanyaan kenapa pemerintah Islam dimasa lalu tidak mengembangkan institusi ini telah dijelaskan dalam bagian pertama mengenai landasan sosial yang menghambat pembentukan korporasi didunia Muslim.

\footnotetext{
${ }^{35}$ Khan, op.cit, hlm.176. Para imam tersebut berpendapat sebagai bentuk syarikat al-milk maka pencuri itu sendiri berhak atas bagian harta yang menjadi miliknya sendiri atau dengan kata lain, pencuri harta baitul maal itu tidak sepenuhnya mencuri karena dia memiliki hak atas mal musytarak yang melekat atas objek mal musytarak yang melekat dalam baitul maal.
} 


\section{Penutup}

Terlambatnya perkembangan organisasi bisnis korporasi di dunia Muslim disebabkan oleh pelbagai faktor diantaranya; adanya pandangan bahwa pengorganisasi kelompok masyarakat dapat merusak visi persatuan umat karena dapat menimbulkan faksionalisasi di tengah masyarakat; tersedotnya sumber daya modal masyarakat kedalam institusi wakaf; mandeknya pengembangan institusional organisasi bisnis dalam hukum Islam; dan tidak terkonsolidasinya kelas pengusaha Islam akibat sulitnya akumulasi modal secara berkesinambungan antar generasi maupun antar konglomerasi.

Terminologi dhimmah ini sangat serupa dengan konsep personalitas dalam hukum barat bahkan lebih detil daripada konsep personalitas itu sendiri. Namun terdapat perbedaan mendasar dari jangkauan hukumnya, dimana dhimmah ini tidak hanya menjangkau aspek duniawi namun juga dimensi akhirat. Oleh karena itu setiap bentuk personalitas dalam Islam haruslah dapat dibebani hak dan kewajiban dunia dan akhirat. Dalam pemikiran fuqoha, dhimmah hanya bisa diberikan kepada manusia saja atau dalam istilahan hanya terbatas pada mukallaf saja. Apabila suatu institusi memiliki status personalitas maka bagaimana bisa membebaninya dengan kewajiban ibadah. Dengan kata lain, fuqoha sebenarnya memahami kemungkinan berlakunya konsep dhimmah bagi corpus selain manusia, akan tetapi mereka enggan mengembangkan konsep ini karena tidak dapat bekerja dalam sistem hukum yang mereka ciptakan. Adapun pembentukan dhimmah nonmanusia sebenarnya dimungkinkan dalam Islam karena merupakan siyasah syariyah yang menjadi domain ulil amri (political authority). 


\section{Daftar Pustaka}

\section{Buku}

Abu Zahrah, Muhammad. Ushul Fiqih. Jakarta:Pustaka Firdaus, 2014.

Anshori, Abdul Ghofur. Perbankan Syariah di Indonesia. Yogyakarta: Gadjah Mada University Press, 2009.

August, Ray. International Business Law; Text, Cases, and Reading.New Jersey: Pearson Prentice Hall, 2009.

Ibn al-Humam al-Siwasi al-Iskandari, Kamal al-Din Muhammad. Fath al-Qadir a'la al-Hidayah Sharh Bidayat al-Mubtadi. Cairo: Mustafa al-Babi al-Halabi, 1970.

Kuran, Timur.The Long Divergence.New Jersey: Princenton University Press, 2013.

Landes, David.Banker and Pashas: International Finance and Economic Imperialism in Egypt Washington: Harvard University Press, 1958.

Nyazee, Imran Ahsan. Islamic Law of Business Organization (Partnership), Selangor: The Other Press, 2006.

Nyazee, Imran Ahsan. Fikih Korporasi :Membincang Hukum Organisasi Bisnis Dalam Islam. Diterjemahkan olehNafis Irkhami, dkk. Salatiga:STAIN Salatiga Press, 2008.

Nyazee, Imran Ahsan. Islamic Law of Bussiness Organization(Corporations). Pakistan:The International Institute of Islamic Thought,1998.

Schamell, Earnest H. Lindley on the law of Partnership 12th ed. London: Sweet and Maxwell, 1962.

Sulistyowati \& Shidarta, eds. Metode Penelitian Hukum Dalam Konstelasi dan Refleksi.Jakarta:Yayasan Pustaka Obor, 2013.

Udovitch, Abraham L. Partnership and Profit in Medieval Islam. New Jersey: Princenton University Press, 1970.

\section{Artikel}

Gaodiosi, M. "The Influence of the Islamic Law Waqf on the Development of the Trust in England: The Case on Merton College.", Pennsylvania Law Review, Vol. 136, (1988).

Hansman, Henry, dkk. "Law and the Rise of the Firm", Harvard Law Review, Vol. 119, (2006). 
Hasanuzzaman, S. M. "Limited Liability of Shareholder: an Islamic Perspective”, Islamic Studies, Vol. 8, No. 24, (1989).

Kuran, Timur. "The Islamic Commercial Crisis: Institutional Roots of Economic Underdevelopment in the Middle East", Journal of Economic History, Vol. 63, (2003).

Labib, Subhi Y. "Capitalism in Medieval Islam", The Journal of Economic History, Vol. 29, (1969).

Tignor, Robert L. "The Introduction of Modern Banking into Egypt 1855-1920”, Asian \& Africa Studies, Vol. 15. (1981). 